Pollock, M. R. (1956). J. gen. Microbiol. 14, 90-108

\title{
An Immunological Study of the Constitutive and the Penicillin-induced Penicillinases of Bacillus cereus, Based on Specific Enzyme Neutralization by Antibody
}

\author{
BY M. R. POLLOCK
}

National Institute for Medical Research, Mill Hill, London, N.W.7

SUMMARY: Exocellular penicillinases from strains 569 and 5/B of Bacillus cereus gave almost identical activity-neutralization curves when titrated with antisera prepared against the enzyme from either strain; but were easily distinguishable by differences in their neutralization reaction with an anti-569 penicillinase serum previously partially absorbed with either the 5/B or the 569 enzyme. By contrast, no differences in neutralization reaction were detected between basal and induced penicillinase from strain 569 and the constitutive penicillinase from strain $569 / \mathrm{H}$ (a mutant derived from strain 569), when treated with samples of the anti-569 penicillinase serum, previously partially absorbed with each penicillinase preparation separately.

Strain 569 was not found to produce any substance in significant quantities capable of combining with anti-penicillinase neutralizing antibodies other than penicillinase itself.

Although it has been known for many years that enzymically active proteins may evoke the production of precipitating and neutralizing antibodies in animals, relatively little systematic work has been done on the neutralization reaction. Toxin neutralization by specific antitoxin has of course been investigated in detail, but, except in those cases where the toxin is itself enzymically active and has a well-defined substrate, such studies suffer from the disadvantages of cumbrous and inaccurate in vivo titration of biological activity. In those instances where an enzyme stimulates the formation of antibodies which will neutralize-to a greater or lesser extent-enzymic activity, the antigen-antibody reaction can be studied quantitatively at relatively low concentrations of the reagents from an aspect which is distinct from the precipitation reaction and can thus be expected to shed new light on the character of the specific combination. Some of the possibilities offered by such studies of enzyme-antibody reactions have been outlined in a stimulating article by Cinader (1953); and the subject has been reviewed by Sevag (1951).

Quite apart from its general immunological interest, the pioneer work of Cohn \& Torriani $(1952,1953)$ on the properties of induced $\beta$-galactosidase and the related protein $\mathrm{Pz}$ in Escherichia coli has shown clearly the advantages to be gained by the application of immunological methods to the study of induced enzyme synthesis in micro-organisms. Housewright \& Henry (1947) showed that penicillinase from Bacillus cereus, strain 569 can evoke the production of penicillinase-inhibiting antibodies in rabbits. The present work was begun as an immunological analysis of penicillinase induction, analogous to that carried out by Cohn \& Torriani on $\beta$-galactosidase formation in Escherichia 
$c o l i$, and has been extended to include a detailed immunological comparison of the induced, basal, and constitutive exocellular penicillinases formed by Bacillus cereus strains with or without treatment by penicillin (see Kogut, Pollock \& Tridgell, 1956).

\section{METHODS}

Enzyme preparations for immunization. (a) Induced penicillinase from Bacillus cereus, strain 569 grown in a peptone medium, and purified (Pollock \& Torriani, 1953) to an extent which subsequent work (Kogut et al. 1956) showed was about $50 \%$ pure. Subsequently referred to as induced 569 penicillinase.

(b) Constitutive penicillinase from Bacillus cereus, strain 5/B-a strain physiologically distinct from strain 569-being a constitutive penicillinase mutant derived from the non-inducible $B$. cereus, strain 5 (Sneath, 1955): used at a stage in isolation which further work (Pollock, Torriani \& Tridgell, 1956) showed to have been $60 \%$ pure. Subsequently referred to as $5 / B$ penicillinase.

Enzyme preparation for in vitro reactions with antibodies. (a) Induced 569 penicillinase: apparently pure, as judged by electrophoretic and ultracentrifugal analysis (Kogut et al. 1956).

(b) Basal penicillinase from Bacillus cereus, strain 569: formed without induction by penicillin (impure preparation: see Kogut et al. 1956); subsequently referred to as basal 569 penicillinase.

(c) Constitutive penicillinase from Bacillus cereus, strain 569/H (constitutive mutant from strain 569): apparently pure, judged by electrophoresis and ultracentrifugal analysis (Kogut et al. 1956); subsequently referred to as $569 / \mathrm{H}$ penicillinase.

(d) 5/B penicillinase: crystalline preparation (Pollock et. al. 1956).

Immunization. (a) Induced 569 penicillinase. $4 \mathrm{mg}$. of the enzyme preparation in a volume of $\mathbf{2 . 0} \mathrm{ml}$. were injected into the subscapular region of each of three rabbits $(359,360$ and 362) after homogenizing with Freund's adjuvant (Freund, Thomson, Hough, Sommer \& Pisani, 1948). Four weeks later each rabbit received five further intravenous injections on alternate days of about $0.5 \mathrm{mg}$. of enzyme preparation adsorbed on aluminium hydroxide. This 'alum precipitated' enzyme was prepared by adding $7.5 \mathrm{ml}$. of the enzyme solution in $0.01 \mathrm{~m}$-phosphate $(\mathrm{pH} \mathrm{7.0)}$ to $0.25 \mathrm{ml}$. of $1 \%$ ammonium alum. The aluminium hydroxide, with absorbed enzyme, was allowed to flocculate overnight and resuspended by mixing before injection. The rabbits were bled white 10 days after the last injection and the sera separated. The sera are subsequently referred to as anti-569. The serum from each rabbit was kept separate and distinguished by the animal's number added in brackets, e.g. anti-569 $(362)$.

(b) 5/B penicillinase. Three rabbits (1,2 and 3 ) each received six intravenous injections of about $0.5 \mathrm{mg}$. of alum-precipitated enzyme per injection over the course of 3 weeks, and were bled white 8 days after the last injection, and the sera separated. The sera are subsequently referred to as anti-5/B.

Further treatment of antiserum. The crude $\gamma$-globulin fraction of rabbit 362 antiserum (which had the highest anti-penicillinase titres and on which 
most of the work was done) was precipitated with ethanol by a technique based on that described by Nichol \& Deutsch (1948) as follows. $50 \mathrm{ml}$. of serum were diluted to $150 \mathrm{ml}$. with $0 \cdot 85 \%$ saline, adjusted to $\mathrm{pH} 7 \cdot 6$ by addition of $\mathrm{N}-\mathrm{HCl}$ and cooled in a freezing bath until ice crystals began to form. $50 \mathrm{ml}$. ethanol, previously cooled to $-\mathbf{2 0}^{\circ}$, were added slowly, with constant stirring, and the precipitate allowed to settle ( $1 \frac{1}{2} \mathrm{hr}$.), centrifuged off and dissolved in saline containing $0.01 \mathrm{~m}$-phosphate $\mathrm{pH} 7.0$ (vol. $20 \mathrm{ml}$.). The solution was freeze-dried in ampoules in $2.0 \mathrm{ml}$. lots (corresponding to $5.0 \mathrm{ml}$. of the original serum) and dissolved in $5.0 \mathrm{ml}$. saline before use so that antibody concentration was the same as that in the original serum and antibody titres could be compared directly with those in untreated whole sera. The overall loss of anti-penicillinase activity by this precipitation method was found to be negligible. The other antisera were freeze-dried and sealed in ampoules, without further treatment.

Enzyme neutralization tests. These correspond to constant antigen titrations. They were done at very low concentrations of antigen (from 0.03 to $0 \cdot 2 \mu \mathrm{g}$. purified enzyme $/ \mathrm{ml}$.) and antibody in the presence of $1 \%(\mathrm{w} / \mathrm{v})$ gelatin by mixing a series of $1.0 \mathrm{ml}$. samples of the enzyme solution with $0.5 \mathrm{ml}$. of saline containing varying concentrations of antibody. The mixture was allowed to stand $30 \mathrm{~min}$. at room temperature, and the enzyme activity assayed, on $1.0 \mathrm{ml}$. samples, manometrically by the method of Henry \& Housewright (1947). The error of this assay technique is not more than $5 \%$. Experiments on antibody from rabbit 362 showed that the neutralization reaction between enzyme and antigen was complete within $10 \mathrm{~min}$. at room temperature. In antigen excess the amount of enzyme activity neutralized (whatever the concentration of enzyme) is directly proportional to the quantity of antibody added, so that it is permissible to define an anti-penicillinase neutralization unit (N.U.) as being that quantity capable of neutralizing 1 unit of enzyme (defined by Pollock \& Torriani, 1953) in a mixture where enzyme is in excess (i.e. not all in combination with antibody). In practice, the neutralization titre of any given antibody solution can be calculated directly from the slope of the linear portion of the neutralization curve (see later in text). Repeat estimations of neutralization titre against one particular enzyme never differed by more than $20 \%$. Normal rabbit serum, diluted $1 / 2$, produced no detectable inhibition of 100 units induced 569 enzyme $/ \mathrm{ml}$.

Antibody absorption test. This corresponds to a constant antibody titration. Varying amounts (usually between 10 and $20 \mu \mathrm{g}$.) of enzyme were added to a constant amount of antibody (usually corresponding to between 0.06 and $2.5 \mathrm{ml}$. of undiluted serum) in saline containing $0.01 \mathrm{M}$-phosphate $(\mathrm{pH} \mathrm{7.0})$ in a final volume of $\mathbf{3 . 0} \mathrm{ml}$. At this relatively high enzyme concentration no gelatin is necessary in order to prevent inactivation. The mixture was left at $\mathbf{3 5}^{\circ}$ overnight, and the precipitate spun off, washed when necessary, and resuspended in the same volume of buffered saline. The supernatant fluid was assayed for enzyme activity after suitable dilution in $1 \%$ aqueous gelatin and its residual enzyme-neutralization titre estimated as described above. The enzyme activity in the evenly resuspended precipitate was similarly assayed. 


\section{RESULTS}

\section{Enzyme neutralization}

Fig. 1 illustrates a typical neutralization curve obtained when increasing amounts of anti-569 (362) antibody were added to a given quantity of 569 induced penicillinase. The following points should be emphasized:

(1) After mixture with antibody the enzymic hydrolysis of penicillin proceeds at a decreased but strictly linear rate in the usual way until at least $95 \%$ of the substrate is destroyed; and five-fold variation in initial penicillin concentration $\left(10^{-2} \mathrm{M}\right.$ to $\left.2 \times 10^{-3} \mathrm{M}\right)$ caused no difference in the rate of hydrolysis by antibody-inhibited enzyme. It can therefore be concluded that, once

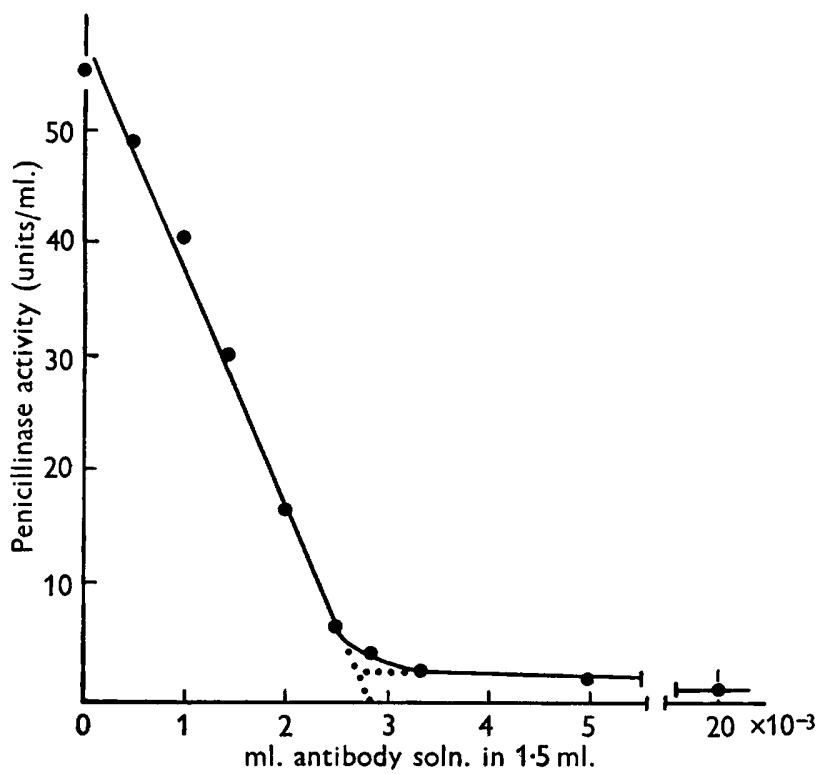

Fig. 1. Neutralization curve of purified induced 569 penicillinase with anti-569 penicillinase $\gamma$-globulin (362) preparation.

combination between enzyme and antibody has occurred, it cannot easily be reversed by addition of substrate. The effect of adding antibody to enzymesubstrate mixtures (i.e. during the course of penicillin hydrolysis) has not been studied here, although Housewright \& Henry (1947) found that maximum inhibition of enzyme activity was attained within $60 \mathrm{~min}$. of antiserum addition.

(2) The curve is approximately linear over $95 \%$ of its course-i.e. the amount of enzyme activity neutralized is proportional to the quantity of antibody added. From the slope the anti-569 neutralization titre of the antibody preparation can be calculated.

(3) The neutralization titre is not affected significantly either by variations in the concentration of enzyme employed or the presence of other substances. It was found that the antibody had quantitatively the same neutralizing action 
against pure enzyme preparation as against enzyme in untreated culture supernatant fluid. Even the presence of intact cells or extracts from crushed cells (from an uninduced culture of strain 569) at a concentration of $1 \mathrm{mg}$. dry weight $/ \mathrm{ml}$. was not found to affect the neutralization reaction significantly.

(4) The small amount of residual activity not neutralizable even by gross excess of antibody is apparently due to the activity of the enzyme antibody complex itself. This was shown in precipitation tests by resuspending the precipitate and measuring its enzymic activity in the usual way (see Table 1 and later in text). As long as antibody was in excess no significant enzyme activity was detectable in the supernatant fluid after removal of the enzyme + antibody precipitate by centrifugation. All the residual activity, under such conditions, remained in the precipitate. The true equivalence point-(i.e. antigencombining titre), where enzyme and antibody are in combination with no appreciable free enzyme or antibody present-is thus probably best indicated by the point of intersection of the linear portion of the neutralization curve with the extrapolation of a line joining the points obtained in the region of antibody excess. In the case illustrated in Fig. 1, the activity of enzymeantibody complex was very low and the enzyme-combining titre of antibody did not differ much from the enzyme-neutralizing titre. But in other cases (see Fig. $2 a, b$, and later) there may be a big difference. It was confirmed by enzyme/antibody precipitation tests (in excess antibody) that, in the case of anti-569 (362) antibody the quantity of neutralizing antibody removed by precipitation with enzyme did not differ by more than $20 \%$ from that expected from the antigen-combining titre calculated from direct enzyme-neutralization curves.

\section{Homologous and heterologous neutralization}

Fig. 2 illustrates the four pairs of neutralization curves obtained when two anti-569 (Fig. $2 a$ (i) and (ii)) and two anti-5/B (Fig. $2 b$ (i) and (ii)) sera were titrated against both induced 569 and $5 / \mathrm{B}$ penicillinases. The salient points may be summarized:

(1) Although the four antisera differed from one another considerably in their neutralization titres, there was no marked difference between the two enzymes in the extent to which they were neutralized by any of the antisera.

(2) The two anti-5/B sera had lower neutralizing titres and gave much higher residual activities than the two anti-569 sera. Since the anti-5/B and anti-569 sera were not prepared by the same immunization technique it is not possible to decide whether this was due to differences in the immunizing antigen or in the immunizing technique. However, the two anti-5/B sera themselves differed from one another both in neutralization titre and residual activity in antibody excess. Calculations show, however, that the equivalence point (i.e. the antigen-combining titre) is almost exactly the same for the two sera. They probably differed, therefore, only in the activity of the enzyme-antibody complex. Since in this case the immunization techniques and immunizing antigens were identical, the variation must lie in the antibody-forming systems of the two rabbits such that the induced antibody molecules apparently differed in their ability to neutralize the enzyme activity when combined. 


\section{Precipitation tests}

Enzyme-antibody precipitates. Table 1 shows the proportions of the original enzyme activity remaining in the resuspended precipitate formed after addition of antibody. The values correspond approximately to the proportion of residual activity in antibody excess found in the direct neutralization test,

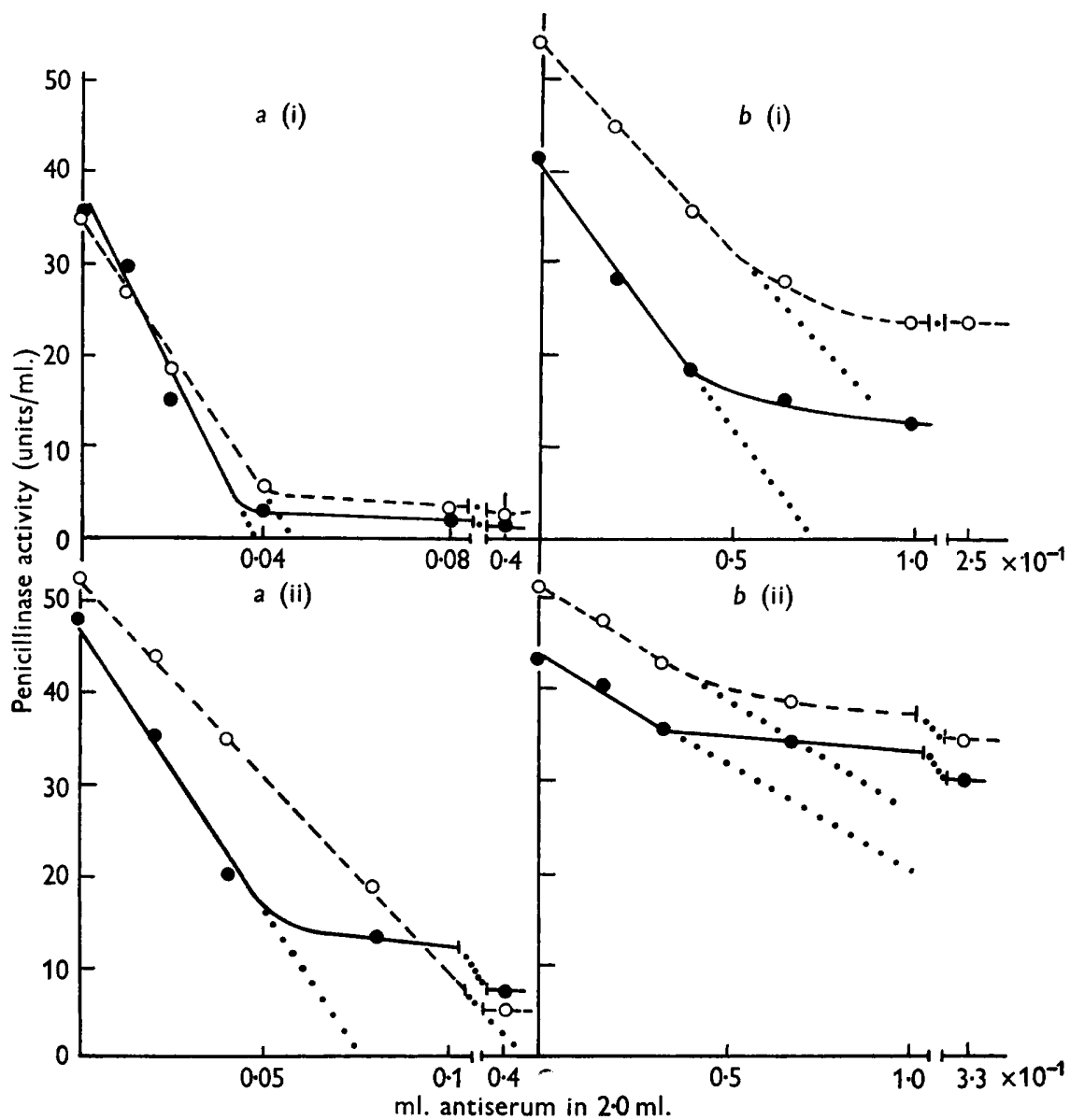

Fig. 2. Neutralization of penicillinase activity by four antisera (unabsorbed) prepared against: $(a)$ induced 569 penicillinase in (i) rabbit 362 , (ii) rabbit 360 , and $(b) 5 / \mathrm{B}$ penicillinase in (i) rabbit 1 , (ii) rabbit 2 ; and titrated against both induced 569

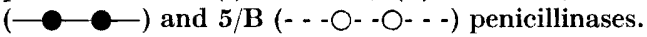

and there is clearly a marked difference between anti-5/B and anti-569 antisera in the extent to which enzyme activity is neutralized by combination with antibody. The enzyme + antibody precipitate (washed twice with saline) formed in excess enzyme appeared to be slightly more active than when formed in excess antibody. With anti-569 (362) antibodies, the enyzme + antibody precipitate appeared to be almost completely insoluble and the complex to be 
stable (at least in the absence of substrate). Repeated washing and resuspension of the precipitate in saline did not cause any significant decrease in its activity, or appearance of activity in the washings (Table 2 ).

\section{Table 1. Enzyme activities of penicillinase/anti-penicillinase precipitates}

Varying quantities of enzyme and antiserum were mixed in a final vol. of $3.0 \mathrm{ml}$. saline containing 0.01 M-phosphate (pH 7.0) and, after incubation at $35^{\circ}$ for $16 \mathrm{hr}$, , the precipitate was centrifuged down, washed in buffered saline, resuspended and assayed for enzymic activity. The supernatant fluid was assayed for enzyme activity and titrated for neutralizing ability against the enzyme used for precipitation.

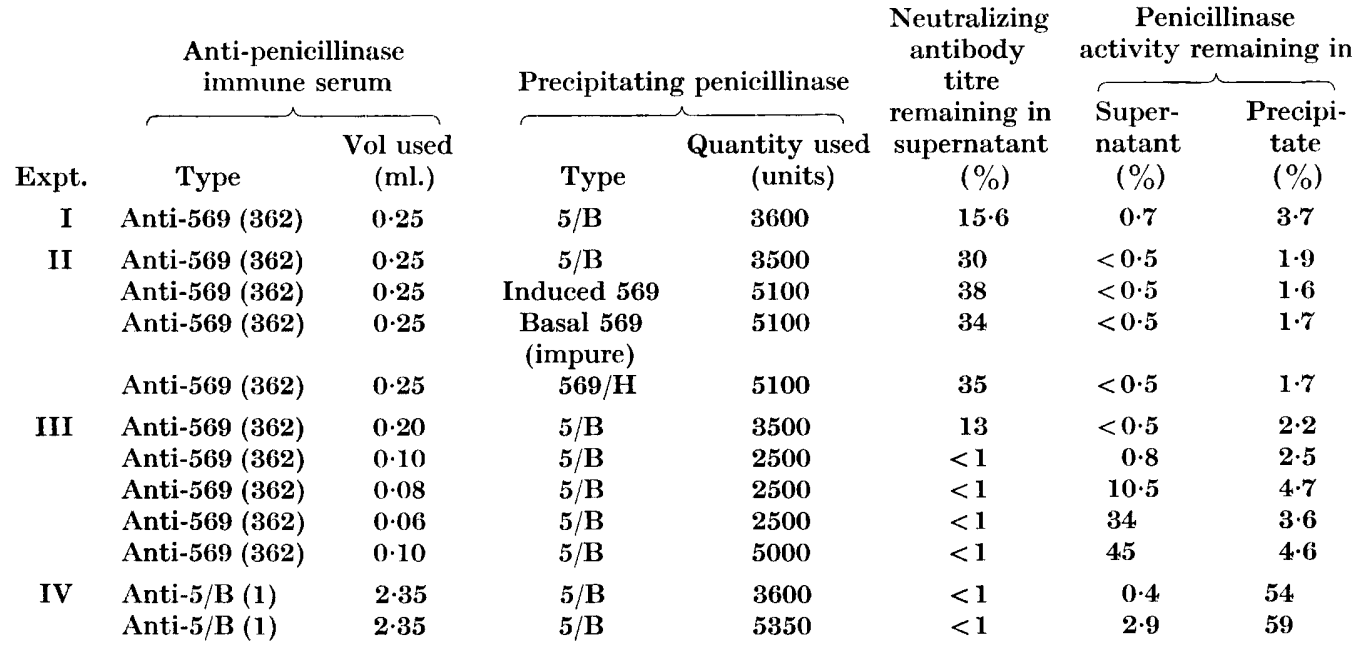

Table 2. Stability of penicillinase/anti-penicillinase precipitate on repeated washing

21,300 units of induced 569 penicillinase were mixed with $0.75 \mathrm{ml}$. of anti-569 (362) $\gamma$-globulin (i.e. antibody excess) in $9.0 \mathrm{ml}$. of buffered saline. After incubation at $35^{\circ}$ for $16 \mathrm{hr}$. the precipitate was centrifuged down and resuspended in the same volume of buffered saline. After leaving for at least $24 \mathrm{hr}$. at $+2^{\circ}$ the enzymic activity was assayed in duplicate, the precipitate centrifuged down again and resuspended, at the same concentration, in buffered saline, while the supernatant fluid from the centrifugation was also assayed for activity. This procedure was repeated five times.

Penicillinase activity of

No. of resuspensions of precipitate in buffer saline

\begin{tabular}{|c|c|}
\hline $\begin{array}{c}\text { Resuspended } \\
\text { precipitate }\end{array}$ & $\begin{array}{l}\text { Washings } \\
\text { nl.) }\end{array}$ \\
\hline $46 \cdot 5$ & $<1 \cdot 0$ \\
\hline $51 \cdot 0$ & $<1 \cdot 0$ \\
\hline $51 \cdot 5$ & $<1 \cdot 0$ \\
\hline $\begin{array}{l}48 \cdot 5 \\
49 \cdot 2\end{array}$ & $<1 \cdot 0$ \\
\hline $51 \cdot 2$ & $1 \cdot 0$ \\
\hline
\end{tabular}


Complete absorption of antibodies. By adding enzyme to antibody to the point when free enzyme began to appear in the supernatant fluid after centrifuging off the precipitate (= equivalence point), it was possible to remove all, or very nearly all, the neutralizing antibodies to both types of enzyme with equivalent amounts of either $5 / \mathrm{B}$ or induced 569 penicillinase (see Table 3 ).

\section{Table 3. Removal of neutralizing antibodies from anti-penicillinase immune} serum by absorption with homologous and heterologous penicillinases

The antibody and enzyme solutions were mixed in a final vol. of $3.0 \mathrm{ml}$. saline containing $0.01 \mathrm{~m}$-phosphate $\left(\mathrm{pH} 7.0\right.$ ) and incubated for $16 \mathrm{hr}$. at $35^{\circ}$, after which the precipitate was centrifuged down and the supernatant fluid assayed for penicillinase activity and penicillinase-neutralizing ability.

\begin{tabular}{|c|c|c|}
\hline \multirow{2}{*}{$\begin{array}{l}\text { Amount of } \\
\text { anti-569 } \\
\text { penicillinase } \\
\text { serum } \\
\text { (ml.) }\end{array}$} & \multicolumn{2}{|c|}{ Absorbing penicillinase } \\
\hline & Type & $\begin{array}{c}\text { Quantity } \\
\text { (units) }\end{array}$ \\
\hline 0.25 & $\begin{array}{c}\text { Induced } \\
569\end{array}$ & 8700 \\
\hline $0 \cdot 25$ & $5 / \mathbf{B}$ & 5500 \\
\hline
\end{tabular}

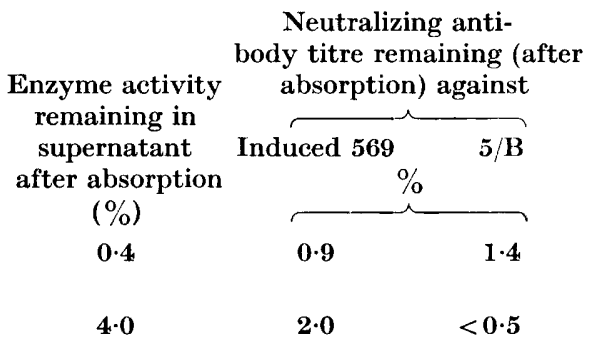

Table 4. Constant antibody titration for determining the equivalence point of combination between 5/B penicillinase and anti-569 antibody in the precipitation reaction

Varying quantities of crystalline $5 / \mathrm{B}$ penicillinase were mixed with $0.06 \mathrm{ml}$. of anti-569 (362) undiluted $\gamma$-globulin solution in physiological saline containing $0.01 \mathrm{~m}$-phosphate $(\mathrm{pH} \mathrm{7.0)}$ in a final volume of $3.0 \mathrm{ml}$. and incubated for $16 \mathrm{hr}$. at $35^{\circ}$. The precipitate was centrifuged off and the enzyme activity remaining in the supernatant fluid was assayed. 'Equivalence' point of enzyme/antibody reaction expressed as amount of $5 / B$ enzyme combined with $1.0 \mathrm{ml}$. undiluted antibody solution: calculated from table below: 24,970 units; calculated from neutralization curve (not shown): 26,800 units.

Total amount of penicillinase found in super-

Amount of 5/B penicillinase added (units)

1340

1600

2000

2400

2800

3200 natant after removal of precipitate (units)

$<6$
46
395
1040
1310
1720

Total amount of penicillinase precipitated (units)

1334

1554

1605 Mean

1360 value:

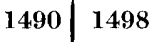

1480

When larger amounts of enzyme were added, all the excess enzyme activity appeared in the supernatant fluid; Table 4 shows that the total amount of enzyme precipitated by a given amount of antibody did not vary significantly, after the equivalence point was reached, even in the regions of marked antigen excess.

Up to this point there appeared to be no clear evidence of any immunological differences between the induced 569 and 5/B penicillinases. Indeed, it might 
well have been argued that the similarity of the neutralization slopes and the results of the absorption tests were good evidence in favour of the two enzymes being identical. However, it was noticed on repeated tests that anti569 (362) antibody gave consistently slightly higher neutralization titres against the induced 569 penicillinase than against the 5/B enzyme, the mean difference being $35 \%$. Further work, restricted entirely to the higher titre anti-569 (362) antiserum, on the effect of partial absorption of antibodies, showed conclusively that the induced 569 and $5 / B$ penicillinases were immunologically distinct.

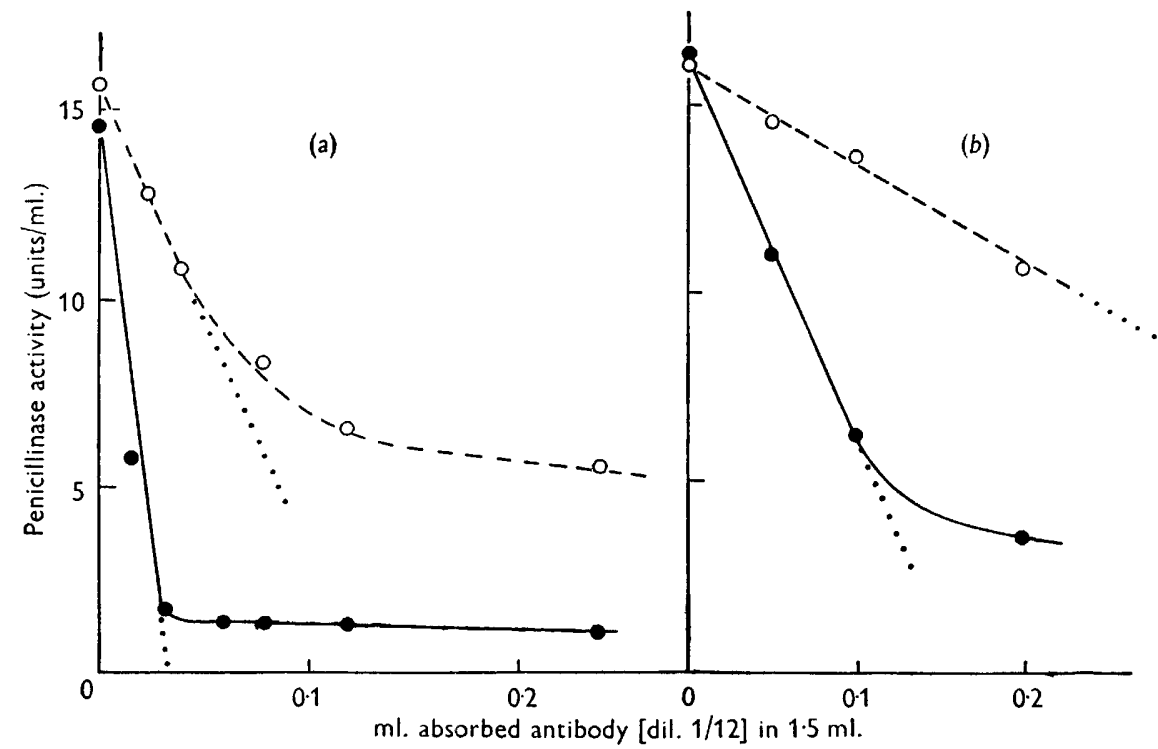

Fig. 3. Neutralization of penicillinase activity by anti-569 penicillinase antibody (362) solution partially absorbed by mixing $0.25 \mathrm{ml}$. with $(a) 5 / \mathrm{B}$ penicillinase $(4300$ units) and $(b)$ induced 569 penicillinase (8500 units). After removal of the precipitate, the supernatant fluid was titrated for neutralizing activity against both induced 569 $\left(-\bigcirc_{-}\right)$and 5/B (- - - $\left.--_{-}-_{--}\right)$penicillinases. See text.

Partial absorption of antibodies. When enough enzyme (either induced 569 or 5/B) was added to the anti-569 antibody preparation to decrease its neutralizing titre by about $70 \%$, it was found that relative neutralization titres against induced 569 and $5 / \mathrm{B}$-expressed as a simple ratio-rose from $\mathbf{1} \cdot \mathbf{4}$ to $2 \cdot 6$, and finally (with $90 \%$ absorption) to $4 \cdot 0$. This finding is illustrated in Fig. 3, where the neutralization curves of anti-569 (362) antibody against induced 569 and 5/B are compared after partial absorption of antibodies $(a)$ with $5 / \mathrm{B},(b)$ with induced 569 penicillinase. These curves should be compared with those shown by the same antibody preparation before absorption (Fig. $2 a$ (i)). As well as a three-fold increase in the anti-induced 569/anti-5/B neutralizing ratio, there is, as seen in the case of the $5 / \mathrm{B}$-absorbed antibody preparation, a marked qualitative change in the anti-5/B neutralization curve which shows higher residual activity in excess antibody and a departure from 
linearity after only $\mathbf{2 5} \%$ of the enzyme had been neutralized (compared with about $80 \%$ with unabsorbed serum). The enzyme neutralization titres of these absorbed antibody preparations have been calculated as maximum titres-i.e. in the presence of sufficient excess enzyme for there to be direct proportionality between enzyme neutralized and antibody added (linear portion of the neutralization curve).

It was also found that the antibody remaining after $90 \%$ reduction in neutralizing titre by absorption with $5 / \mathbf{B}$, failed to give a precipitate with 5/B enzyme. However, the unabsorbed antibody solution, diluted to the same extent (as judged by neutralization titre) in normal rabbit $\gamma$-globulin to give the same total $\gamma$-globulin concentration as in the partially absorbed antibody solution, gave an obvious precipitate when mixed with the same quantity of $5 / B$ enzyme.

It thus appears that partially absorbed antibody differed qualitatively as well as quantitatively from unabsorbed antibody in that $(a)$ the shape of the neutralization curve with the heterologous enzyme was quite different, $(b)$ it was relatively much less efficient in neutralizing the heterologous enzyme as compared with the homologous enzyme and $(c)$ although able to neutralize, and therefore to combine with, the heterologous enzyme, it failed to form a visible precipitate.

These results show that the induced 569 penicillinase differed significantly from the $5 / \mathrm{B}$ penicillinase. It might, however, still be argued that if the two enzymes were immunologically heterogeneous, consisting of two or more types of molecule, they might differ only in the proportions of different types present, and not in the types themselves; and it could be maintained that this is not a true immunological distinction. Even if this were admitted it would still be a rigidly consistent difference, because preparations of induced 569 penicillinase of varying degrees of purification and from cultures grown in different media and on different occasions have always given similar neutralization curves with partially absorbed antisera; and the same is true for preparations of 5/B penicillinase. But it must be conceded that if the antibodies evoked by a heterogeneous enzyme preparation were heterogeneous in a complementary fashion, the same sort of results as those described above with partially absorbed antibody might be expected. It might indeed be difficult formally to disprove this hypothesis, but it can be shown to be very unlikely by the experiments illustrated in Fig. 4. If, in fact, the enzymes really were immunologically heterogeneous it should be possible to absorb a proportion of enzyme molecules by precipitation with a limiting quantity of antibody (in a manner, strictly analogous to partial absorption of antibody with enzyme) and to obtain a selected sample of those enzyme molecules which were least 'efficient' in combining with antibody. It would then be surprising if such a sample of 'residual enzyme' did not react differently from the untreated enzyme in the neutralization reaction with antibody. However, Fig. 4 shows that a sample of crystalline 5/B penicillinase, after removal of $80 \%$ of activity by precipitation with anti-569 antibody, did not differ significantly from untreated 5/B enzyme in its neutralization curve with anti-569 antibody (partially 
absorbed with $5 / \mathrm{B}$ penicillinase in order to provide optimal conditions for disclosing a difference). It seems therefore reasonable to conclude that there is a true qualitative immunological difference between the induced 569 and the 5/B penicillinases.

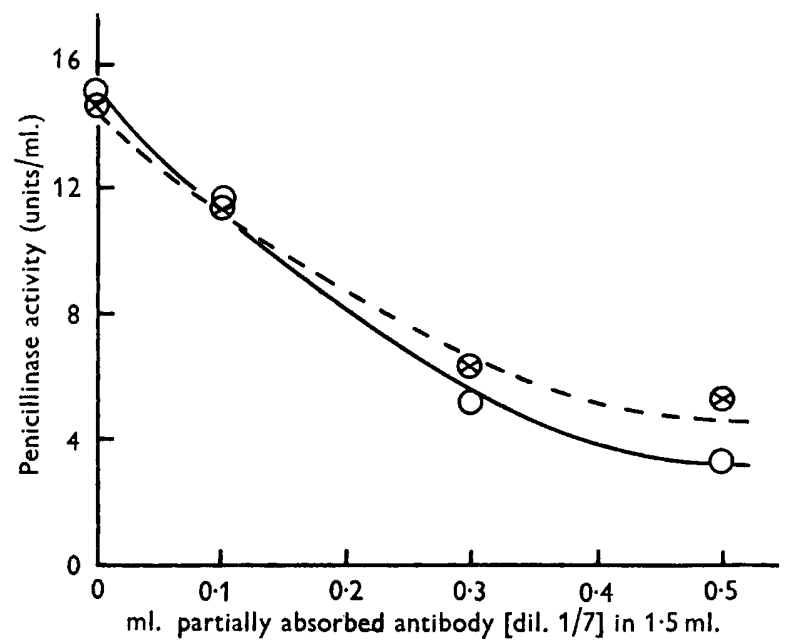

Fig. 4. Neutralization of penicillinase activity of $(a)$ untreated $5 / \mathrm{B}$ enzyme $(-\mathrm{O}-\mathrm{O}-)$ and $(b) 5 / B$ enzyme, reduced in activity by $80 \%$ after partial precipitation with anti-569 (362) antibody (- - $\otimes--\otimes--)$, with anti-569 (362) antibody previously partially (75\%) absorbed with $5 / \mathrm{B}$ penicillinase. The ' $80 \%$ precipitated' enzyme was prepared by mixing 2000 units of crystalline $5 / B$ penicillinase with $0.06 \mathrm{ml}$. anti-569 (362) antibody $\gamma$-globulin solution in a final volume of $3.0 \mathrm{ml}$. physiological saline containing $0.01 \mathrm{M}-$ phosphate $(\mathrm{pH} 7 \cdot 0)$ incubating the mixture for $16 \mathrm{hr}$. at $35^{\circ}$, and centrifuging off the precipitate. $20 \%$ of the original enzyme activity was found left in the supernatant fluid and this was compared with untreated $5 / B$ penicillinase in the neutralization reaction with partially absorbed antibody.

\section{Effect of antiserum on penicillin sensitivity}

In spite of the fact that the penicillin resistance of both strain 5/B and strain 569 of Bacillus cereus is due in large measure to their ability to form penicillinase (see Sneath, 1955), Housewright \& Henry (1947) found that addition of their anti-penicillinase serum to cultures of $B$. cereus strain 569 caused only a slight increase (from 100 to 50 units penicillin/ml. as minimum inhibitory concentration) in penicillin sensitivity. In this work, the addition of 5000 N.u. of anti-569 $\gamma$-globulin $/ \mathrm{ml}$. to broth inoculated with $10^{3}$ spores of strain 569 was not found to lower significantly the minimum penicillin concentration needed to prevent growth. Similar negative results were obtained with spores of strain 5/B inoculated into penicillin-nutrient agar with and without the addition of 500 N.U. anti-569 $\gamma$-globulin $/ \mathrm{ml}$.

\section{Applications}

Immunological comparison of induced and constitutive penicillinases. The clear differentiation between the closely related 5/B and induced 569 penicillinases, provided by neutralization tests with partially absorbed antibody 
preparations, suggested that this technique might be used to look for possible differences between the 569 and $569 / \mathrm{H}$ penicillinases described above. In work reported elsewhere (Pollock et al. 1956; Kogut et al. 1956) the interest of comparing the properties of penicillinases produced before and after induction by penicillin in the same strain, and without induction in a constitutive strain, has been fully discussed in relation to the mechanism of enzyme induction. Previous work (Manson, Pollock \& Tridgell, 1954) had already failed to reveal any differences between basal and induced 569 penicillinase in neutralization tests with unabsorbed anti-569 serum. Although basal
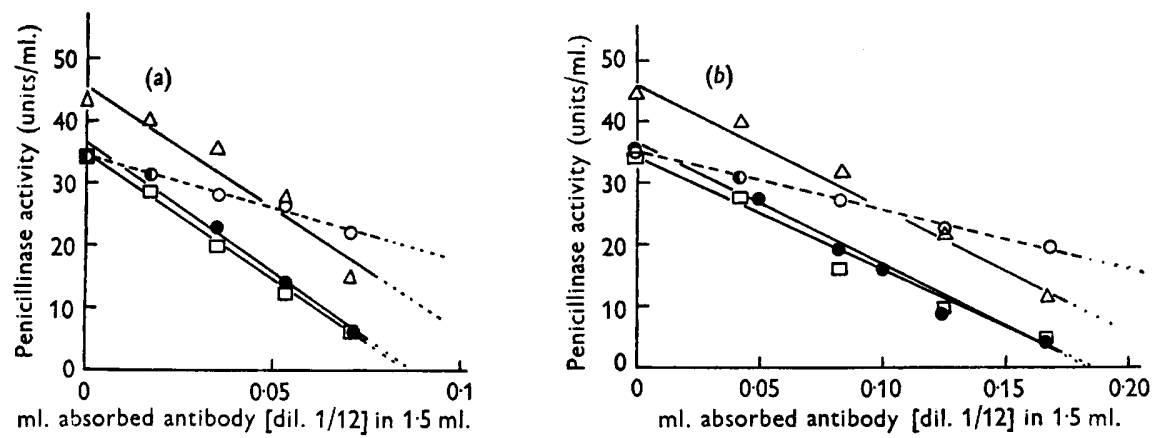

Fig. 5. Neutralization of penicillinase activity by anti-569 penicillinase antibody (362) solution partially absorbed by mixing $0.25 \mathrm{ml}$. with $(a) 5 / \mathrm{B}$ penicillinase (3200 units) and $(b)$ basal 569 penicillinase (5000 units). After removal of the precipitate, the supernatant fluid was titrated for neutralizing activity against basal 569 ( $-\triangle-\triangle-)$,

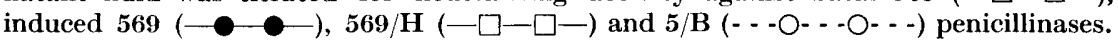
See text and Table 5.

enzyme production is so low that a purified preparation was not available, there was, nevertheless, sufficient of an impure preparation to permit neutralization and absorption tests. Accordingly, neutralization curves of all these 569 enzymes were obtained before and after partial absorption of antibody with each enzyme. The results are summarized in Table 5 and two examples of the families of neutralization curves so obtained are illustrated in Fig. $5 a, b$. It can be seen that: (1) antibody, partially absorbed with any one of the four enzyme preparations, had the same neutralization titre when tested against the two 569 and the $569 / \mathrm{H}$ enzymes (though a different titre against $5 / \mathrm{B}$ ); (2) although in Expt. I there were some differences in the residual antibody neutralization titres after partial absorption with an enzymically equivalent quantity of the 569 and $569 / \mathrm{H}$ penicillinase preparations, they corresponded to an apparent variation of only -11 to $+15 \%$ about the mean in the amount of anti-569 antibodies removed, while in the second experiment the residual titres were almost identical; (3) the ratio of neutralization titres : anti-569/anti5/B, increased from about $\mathbf{1 \cdot 4}$ (for unabsorbed antibody) to $2 \cdot 6$ with $5 / \mathrm{B}$ absorbed antibody. The significant point is not so much the total amount of antibody absorbed by the three different enzyme preparations (small variations being accounted for by relatively slight inaccuracy in estimation of the 


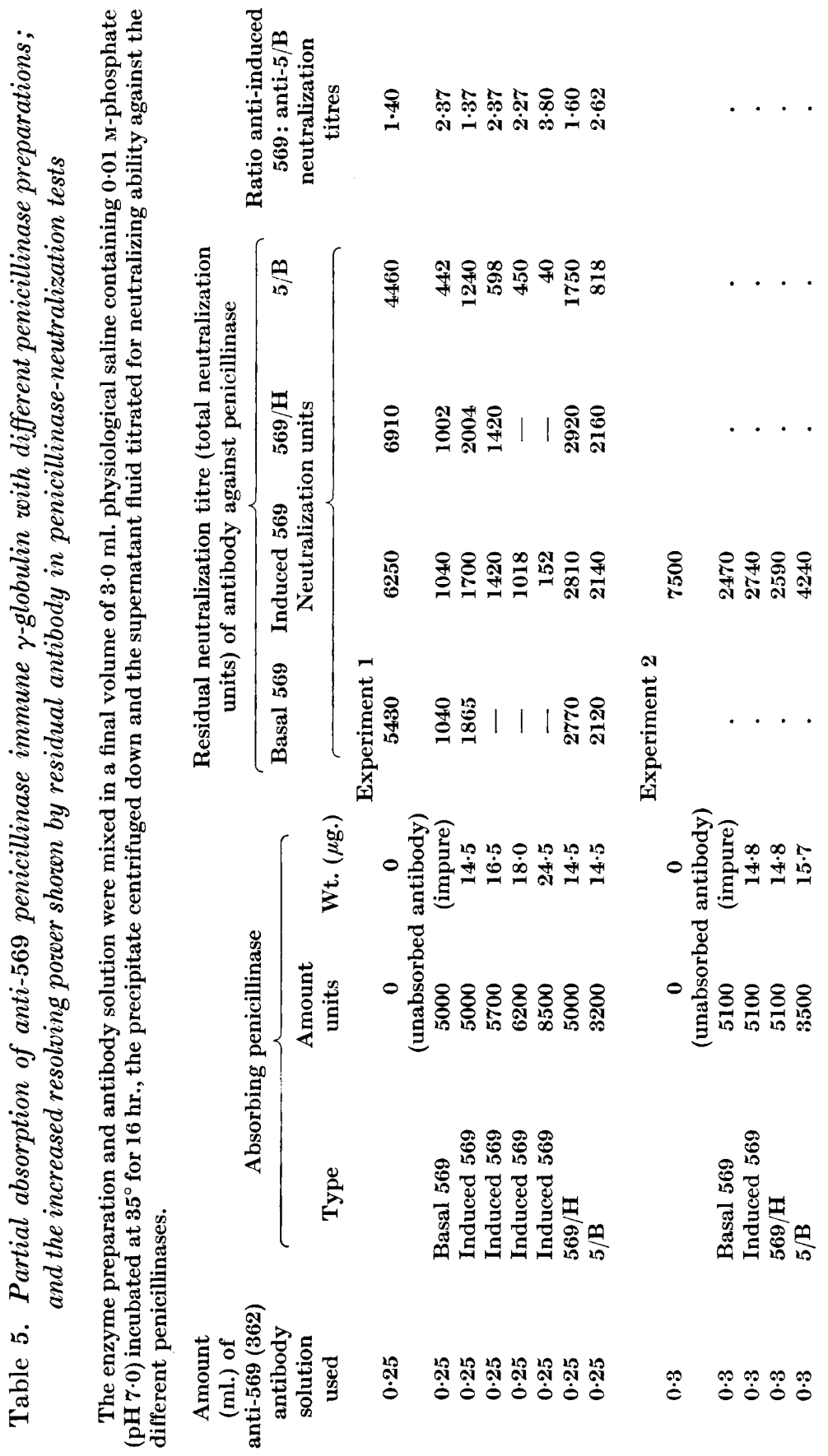


quantity of enzyme added), but the fact that the residual antibody-which might be expected, from its relative neutralizing activity on $5 / \mathrm{B}$ and induced 569 penicillinase, to be capable of differentiating between two similar but distinct enzymes-showed in all cases the same neutralizing action against the 569 and $569 / \mathrm{H}$ penicillinases. Thus, by the immunological techniques employed, these three enzymes must be considered indistinguishable from each other.

Search for other material, in Bacillus cereus strain 569, immunologically related to penicillinase. It can be firmly concluded from the above results that there was no substance present as impurity in the crude basal 569 penicillinase preparation capable of combining with anti-569 neutralizing antibody apart from the penicillinase itself. Such a substance might, however, have been specifically excluded by the isolation procedure employed and its presence either within the cells or in the surrounding media had to be seriously considered in view of the discovery, by Cohn \& Torriani (1953) in Escherichia coli of the protein $\mathrm{Pz}$, immunologically and metabolically related to $\beta$-galactosidase. In order, therefore, to discover whether or not uninduced Bacillus cereus, strain 569, produced any enzymically inactive protein, immunologically related to penicillinase, analogous to the $\mathrm{Pz}$ protein of $\boldsymbol{E}$. coli, a cell-disintegrate and an exocellular protein concentrate were prepared as follows. A $500 \mathrm{ml}$. culture of strain 569 in casein hydrolysate + citrate medium (see Kogut et al. 1956) was incubated without addition of penicillin at $35^{\circ}$ on a shaker until a concentration of organisms equivalent to $0.75 \mathrm{mg}$. dry wt. of bacteria/ml. was reached. Oxine (8-hydroxyquinoline) at a final concentration of $8 \times 10^{-4} \mathrm{M}$ was added to prevent further enzyme production, and the cells separated by centrifugation, washed once in $8 \times 10^{-4} \mathrm{M}$-oxine containing $10^{-2} \mathrm{M}$-phosphate buffer $(\mathrm{pH} 7 \cdot 0$ ) and resuspended in $3.0 \mathrm{ml}$. of the same oxine + buffer solution. The organisms were then disintegrated by crushing at $-\mathbf{3 0} 0^{\circ}$ in a Hughes press. A $\mathbf{2 5 0} \mathrm{ml}$. sample of the culture supernatant fluid was concentrated by evaporation at $37^{\circ}$ under reduced pressure to about $50 \mathrm{ml}$. in the apparatus of Craig (1950) and then further concentrated to $2 \cdot 0 \mathrm{ml}$. by dialysis, under pressure, against $10^{-3} \mathrm{M}$-phosphate ( $\mathrm{pH} 7 \cdot 0$ ). The sac was then tied off and the contents further dialysed against three changes of $500 \mathrm{ml}$. of the $10^{-3}$ M-phosphate buffer. The solution in the sac, which contained a small amount of insoluble matter, was made up to $7.5 \mathrm{ml}$. with the phosphate buffer and the 'protein' (i.e. non-dialysable $\mathbf{N}$ ) content estimated by the Kjeldahl method (Ma \& Zuazaga, 1942). Samples of the disintegrated cell preparation and of the exocellular concentrate of non-dialysable material and of purified induced 569 exopenicillinase were then each mixed with $0.25 \mathrm{ml}$. anti-569 (362) antibody solution. After overnight incubation at $35^{\circ}$, insoluble material was centrifuged off and the supernatant fluids tested for neutralizing activity against induced 569 penicillinase (see Table 6). The amounts of cell-disintegrate and exocellular concentrate used were adjusted to correspond to the product of exactly ten times the quantity of cells which formed the amount of pure induced 569 penicillinase added (itself adjusted so as to absorb nearly all the anti-penicillinase antibodies present). This was done simply in order to increase the significance of a negative result. 
It can be seen from Table 6 that there was only a very slight diminution in antibody titre after treatment with the two preparations from uninduced cells, and it can be concluded with reasonable certainty that there is no appreciable amount of any substance produced by uninduced Bacillus cereus, strain 569 capable of absorbing (and therefore probably combining with) penicillinaseneutralizing antibodies, apart from penicillinase itself.

Table 6. Absorption of anti-penicillinase antibodies by different fractions from Bacillus cereus strain 569

$0.25 \mathrm{ml}$. lots of anti-569 (362) antibody solution were mixed with the 'absorbing material' in a final volume of $3.0 \mathrm{ml}$. of saline containing $0.01 \mathrm{M}$-phosphate $\left(\mathrm{pH} \mathrm{7.0)}\right.$. After incubation at $35^{\circ}$ for $16 \mathrm{hr}$. the insoluble material was centrifuged off and the supernatant fluid titrated for neutralizing ability against induced 569 penicillinase.

\begin{tabular}{|c|c|c|c|c|c|c|}
\hline \multirow[b]{2}{*}{ 'Absorbing' material } & \multirow[b]{2}{*}{$\begin{array}{c}\text { Quantity } \\
\text { added } \\
\text { (mg.) }\end{array}$} & \multirow{2}{*}{$\begin{array}{l}\text { Dry wt. } \\
\text { of bacteria } \\
\text { by which } \\
\text { material was } \\
\text { formed } \\
\text { (mg.) }\end{array}$} & \multirow[b]{2}{*}{$\begin{array}{c}\text { Total } \\
\text { penicillinase } \\
\text { activity } \\
\text { (units) }\end{array}$} & \multicolumn{2}{|c|}{$\begin{array}{l}\text { Total neutralization } \\
\text { titre of antibody }\end{array}$} & \multirow[b]{2}{*}{$\begin{array}{c}\text { Neutralizing } \\
\text { antibody } \\
\text { removed } \\
(\%)\end{array}$} \\
\hline & & & & $\begin{array}{c}\begin{array}{c}\text { Before } \\
\text { absorption } \\
\text { Neutraliza }\end{array} \\
\end{array}$ & $\begin{array}{c}\begin{array}{c}\text { After } \\
\text { absorption } \\
\text { tion units }\end{array} \\
\end{array}$ & \\
\hline $\begin{array}{l}\text { Purified exopenicillinase } \\
\text { (from induced cells) }\end{array}$ & $0 \cdot 023$ & $4 \cdot 5$ & 8000 & 7500 & 455 & 94 \\
\hline $\begin{array}{l}\text { Disintegrated uninduced } \\
\text { cells }\end{array}$ & 45 & 45 & 2 & 7500 & 7050 & 6 \\
\hline $\begin{array}{l}\text { Exocellular concentrate } \\
\text { from uninduced cells }\end{array}$ & 1.07 & 45 & 76 & 7500 & 6700 & $10 \cdot 6$ \\
\hline
\end{tabular}

\section{DISCUSSION}

Absorption of anti-569 (362) antibody preparation with either 569 or 5/B penicillinase removes all, or very nearly all, neutralizing antibodies to both 5/B and 569 enzymes. All the antibody molecules must therefore be capable of combining with both enzymes and it seems to be out of the question that they consist of mixtures of two kinds of antibodies each exclusively directed towards one or other type of penicillinase. Neutralization titres of both anti-569 and anti-5/B unabsorbed sera against 5/B and 569 enzymes differ, at the most, by only $40 \%$. Indeed, since the specific activity of induced 569 penicillinase is, on a weight basis, $37 \%$ higher, or on a molecular basis, $20 \%$ higher (Kogut et al. 1956), than that of $5 / \mathrm{B}$, it almost appears as if a given amount of antibody combined with the same number of antigen molecules-or at least with the same weight of antigen -in both cases. Nevertheless, partial absorption of antibody with either $5 / \mathrm{B}$ or 569 penicillinase leaves a residual antibody fraction able to neutralize four times as much 569 penicillinase activity as $5 / \mathbf{B}$. Although at first sight this may appear surprising it can be understood on the hypothesis that a proportion of antibody evoked by 569 penicillinase is nonspecifically 'inefficient' in the sense that the molecules react more slowly, and with less neutralizing power than the average, with both types of penicillinase. These 'inefficient' antibodies would be selectively left behind on partial absorption with either 569 or 5/B enzyme, but might nevertheless be expected to be relatively more efficient against the homologous antigen. The picture 
would fit well the concept of an 'antibody array' described by Fulton (1953), which visualizes a heterogeneous population of antibody molecules showing a continuous spectrum of antigen-combining properties (e.g. closeness of fit, speed of reaction, etc.). Thus, on the assumption that the antigen-antibody reaction is irreversible, the antibody molecules remaining after nearly complete absorption with antigen might be considered as the most slowly reacting of all amongst a heterogeneous population with widely differing speeds of combination.

In contrast to this non-uniformity of the antibody population, no evidence was found to support the possibility of immunological heterogeneity amongst the enzyme molecules. The residual enzyme activity after precipitation of $80 \%$ of a sample of crystalline $5 / \mathrm{B}$ penicillinase with antibody, was indistinguishable from unabsorbed $5 / \mathrm{B}$ penicillinase in the neutralization reaction with a partially absorbed anti-569 antibody preparation.

In general, antibodies which neutralize the activity of the enzyme used as immunizing antigen are quite inactive against the same type of enzyme obtained from a different source. But cross-neutralization reactions can occur with very closely related enzymes (Miles \& Miles, 1950: Clostridium lecithinases; Kirk \& Sumner, 1932: Jack and Soy bean ureases) and have been studied in some detail by MacFarlane (1950) who found that Clostridium haemolyticum and C. oedematiens lecithinases were both inhibited by antiserum produced in rabbits immunized with either enzyme, but their neutralization slopes (though indistinguishable with anti-oedematiens lecithinase serum) differed by about $100 \%$ with anti-haemolyticum lecithinase serum. Crossprecipitation reactions between enzymes from different sources have been more frequently reported. One of the most accurately studied and interesting is that between horse and beef catalase reported by Campbell \& Fourt (1939) who found that twice as much anti-beef catalase serum was needed to precipitate a given quantity of horse catalase as was needed for precipitation of the same amount of homologous catalase. Thus, although in the case of penicillinase an immunological difference between the induced 569 and the 5/B enzymes was unmistakably disclosed by partial antibody absorption tests, the results of direct neutralization tests indicate a closer relationship than that shown by the ureases, lecithinases and catalases from different species similarly investigated.

By the same argument, the failure to detect any differences between the 569 and $569 / \mathrm{H}$ penicillinases with preparations of an antiserum partially absorbed with each type of enzyme must be considered as good evidence in support of their identity. If, at least, there are any differences between basal and induced 569 and $569 / \mathrm{H}$ penicillinases they must be restricted to parts of the molecule not involved in the combination with, or neutralization by, antibody. This result is consistent with an independent physico-chemical comparison between purified 569 induced and $569 / \mathrm{H}$ penicillinases (Kogut et al. 1956) which revealed no significant differences in electrophoretic mobility, specific activity, sedimentation constant, diffusion coefficient or solubility in ammonium sulphate, while the $5 / \mathrm{B}$ enzyme could be shown to be quite distinct 
from the other penicillinases by these criteria. The fact that the basal penicillinase formed by Bacillus cereus, strain 569 without penicillin is immunologically indistinguishable from the induced penicillinase produced by the same strain after treatment with penicillin gives further support to the hypothesis (previously based largely on kinetic and physico-chemical data) that the mechanisms of their formation, in the absence and presence of inducer respectively, are fundamentally similar.

Fig. 2 shows that there is a variation from 30 to $97 \%$ in the extent to which a penicillinase may be neutralized by excess antiserum. The relative importance of the source of enzyme, method of immunization and individual variation of animals in determining the maximum extent of neutralization has not been studied in detail. However, the difference between antisera from rabbits 1 and 2 (immunized with the same enzyme preparation and by exactly the same technique)-Fig. $2 b$ (i) and (ii)-shows that individual variation in the immunized animal may be an important influence. It is clear that other factors, apart from properties associated with the type of enzyme concerned, may determine the degree of neutralization due to combination with antibody.

Attempts to reveal the presence of a substance formed by uninduced Bacillus cereus, strain 569, bearing the same immunological relationship to penicillinase as the ' $\mathrm{Pz}$ ' protein does to induced $\beta$-galactosidase in Escherichia coli (Cohn \& Torriani, 1952) were unsuccessful; but they do not of course exclude the possibility of there being other proteins related to penicillinase in a manner not demonstrable by the techniques used. The results summarized in Table 6 show conclusively that no substance was formed by strain 569 in significant quantities, capable of combining with penicillinase-neutralizing antibodies other than penicillinase itself; and demonstrate the high specificity of the reaction between enzyme and antibody.

The results reported here have been based almost exclusively on a study of the neutralization reaction between enzyme and antibody. The method is economical of both time and material and, at least in this instance, is unaffected by the presence of other substances (which may complicate the interpretation of the precipitation reaction). No doubt quantitative analyses of antigenantibody precipitates, along classic immunological lines, would give further valuable information.

An interesting and somewhat similar immunological analysis has, indeed, been carried out by Markert \& Owen (1954) and Owen \& Markert (1955) working with tyrosinase in extracts of Glomerella sp. By quantitative precipitation tests (to determine 'equivalence points') they concluded that the tyrosinases from the wild type and a number of mutant strains producing the enzyme at widely differing rates, were immunologically indistinguishable; and that there were no substances present in the extracts capable of combining with anti-tyrosinase antibodies other than tyrosinase itself. It is, perhaps, doubtful whether their technique would have allowed them to recognize a difference as fine as that between the 569 and 5/B penicillinases. But their findings are in accordance with those reported here and elsewhere (Kogut et al. 1956) on penicillin-induced and spontaneous mutational changes in rates of 
penicillinase production by Bacillis cereus, strain 569 , which also indicate that the changes observed are purely quantitative (at a molecular level), the types of enzyme proteins formed in all cases being apparently identical.

I am deeply indebted to Dr Melvin Cohn for much stimulating and helpful advice at the beginning of this work. I am grateful to Dr J. H. Humphrey and Dr Forrest Fulton for discussing the work with me in detail, to Dr P. H. A. Sneath for preparing the anti-5/B penicillinase sera and to Miss Joan Fleming for technical assistance.

\section{REFERENCES}

Campbell, D. H. \& Fourt, L. (1939). Immunochemistry of catalase. J. biol. Chem. $129,377$.

Crnader, B. (1953). Antigen-antibody interaction using enzymes as antigens. Biochem. Soc. Symp. $10,16$.

Conn, M. \& Torrian, A. M. (1952). Immunological studies with the $\beta$-galactosidase and structurally related proteins of Escherichia coli. J. Immunol. 69, 471.

Cohn, M. \& TorrianI, A. M. (1953). The relationships in biosynthesis of the $\beta$-galactosidase- and Pz-proteins in Escherichia coli. Biochim. biophys. Acta, $10,280$.

Craig, L. C. (1950). Versatile laboratory concentration device. Analyt. Chem. 22, 1462.

Freund, J., Thomson, K. J., Hough, H. B., Sommer, H. E. \& Pisani, T. A. (1948). Antibody formation and sensitization with the aid of adjuvants. J. Immunol. 60, 383.

Fulton, F. (1953). The antigenic structure of members of the psittacosis-lymphogranuloma group of viruses: a new hypothesis based on the analogous behaviour of certain Rickettsiae. An. Inst. Med. Trop. 10, 491.

Henry, R. J. \& Housewright, R. D. (1947). Studies on penicillinase. II. Manometric method of assaying penicillinase and penicillin, kinetics of the penicillinpenicillinase reaction, and the effects of inhibitors on penicillinase. J. biol. Chem. $167,559$.

Housewright, R. D. \& Henry, R. J. (1947). Studies on penicillinase. III. The effect of antipenicillinase on penicillin-resistant organisms. J. Bact. 53, 241.

Kirk, J. S. \& Sumner, J. B. (1932). Immunological identity of Soy and Jack bean urease. Proc. Soc. exp. Biol. Med., N.Y. 29, 712.

Kogut, M., Pollock, M. R. \& Tridgell, E. J. (1956). Purification of penicillininduced penicillinase of Bacillus cereus NRRL 569; a comparison of its properties with those of a similarly purified penicillinase produced spontaneously by constitutive mutant strain. Biochem. J. (in the Press).

MA, T. S. \& ZuazaGA, G. (1942). Micro-Kjeldahl determination of nitrogen. A new indicator and an improved rapid method. Industr. Engng Chem. 14, 280.

MacFarlane, M. G. (1950). Biochemistry of bacterial toxins. 4. The lecithinase activity of Clostridium haemolyticum toxin. Biochem. J. 47, 267.

Manson, E. E. D., Pollock, M. R. \& Tridgell, E. J. (1954). A comparison of the properties of penicillinase produced by Bacillus subtilis and Bacillus cereus with and without addition of penicillin. J. gen. Microbiol. 11, 493.

MARKERT, C. L. \& OwEN, R. D. (1954). Immunogenetic studies of tyrosinase specificity. Genetics, 39, 818.

Miles, E. M. \& Mrles, A. A. (1950). The relation of toxicity and enzyme activity in the lecithinases of Clostridium bifermentans and Clostridium welchii. J. gen. Microbiol. 4, 22.

Nichol, J. C. \& Deutsch, H. F. (1948). Biophysical studies of blood plasma proteins: VII. Separation of $\gamma$-globulin from the sera of various animals. J. Amer. chem. Soc. 70, 80. 
Owen, R. D. \& Markert, C. L. (1955). Effect of antisera on tyrosinase in Glomerella extracts. J. Immunol. 74, 257.

Pollock, M. R. \& Torriani, A-M. (1953). Purification et caractéristiques physicochimiques de la pénicillinase de Bacillus cereus. C.R. Acad. Sci., Paris, 237, 276.

Pollock, M. R., Torriani, A-M. \& 'Tridgell, E. J. (1956). Crystalline bacterial penicillinase. Biochem. $J$. (in the Press).

Sevag, M. G. (1951). Immunocatalysis and Related Fields of Bacteriology and Biochemistry, 2nd ed. Springfield, Illinois: C. C. Thomas.

Sneati, P. H. A. (1955). Proof of the spontaneity of a mutation to penicillinase production in Bacillus cereus. J. gen. Microbiol. 13, 561.

(Received 28 July 1955) 